\title{
Biofuels for transportation in 2030: feedstock and production plants in a Swedish county
}

Carolina Ersson, Jonas Ammenberg and Mats Eklund

\section{Linköping University Post Print}

\section{Tweet}

N.B.: When citing this work, cite the original article.

Original Publication:

Carolina Ersson, Jonas Ammenberg and Mats Eklund, Biofuels for transportation in 2030: feedstock and production plants in a Swedish county, 2013, Biofuels, (4), 4, 379-395.

http://dx.doi.org/10.4155/bfs.13.23

Copyright: Future Science

http://www.future-science.com/

Postprint available at: Linköping University Electronic Press

http://urn.kb.se/resolve?urn=urn:nbn:se:liu:diva-102371 


\title{
Biofuels for transportation 2030 \\ - Feedstock and production plants in a Swedish county
}

\author{
Carolina Ersson*, Jonas Ammenberg and Mats Eklund \\ Environmental Technology and Management, \\ Linköping University, SE-581 83 Linköping, Sweden \\ *Corresponding Author, Carolina.Ersson@liu.se, +46 13285638
}

\begin{abstract}
Background: This paper gives insight into whether biofuels for road transport can play an important role in a Swedish county in the year 2030, and contributes to knowledge on how to perform similar studies.

Methodology: Resource-focused assessment including feedstock from the waste sector, agricultural sector, forestry sector and aquatic environments partially considering technological and economic constraints.
\end{abstract}

Results: Two scenarios were used indicating that biofuels could cover almost $30 \%$ and $50 \%$ respectively, of total energy demand for road transport.

Conclusion: Without compromising with food security the study suggests that it is possible to significantly increase the biofuel production, and to do this as an integrated part of the existing society also contributing with positive societal synergies.

\section{Introduction}

The EU growth strategy contains demanding challenges - to remain competitive and have a growing economy, ensure energy security and at the same time reduce greenhouse gas emissions significantly. The long-term objective is to cut greenhouse gas emissions by $80-95 \%$ by 2050, with renewable energy emphasized as an important ingredient [1]. The biofuel sector and its integration to policy have a strong position in this strategy [cf. 2]. However, lately a shift can be noted from pushing to constraining policy and regulations within the EU [eg. 3,4] and strategies concerning "the bioeconomy" [cf. 5] could lead to increased competition for biomass.

While the share of renewable energy has passed $20 \%$ for electricity and $10 \%$ for heating and cooling, the transport sector lags at around $5 \%$ [101]. Therefore, the possibilities and challenges concerning transportation are especially relevant. According to many energy projections and forecasts, biofuels can be expected to contribute significantly to the energy supply of the transport sector for decades to come [cf.6,7-9].

Sweden is a leading country in renewable energy and has reached the national EU 2020 objective of $49 \%$ renewable energy, although being the most ambitious objective in the European Union. Another EU 2020 goal is to have at least 10\% renewable energy in the transport sector, almost met by Sweden in 2011 (9.8 \%) [10]. However, Sweden has set a 
much more ambitious level - to have a fossil-independent vehicle fleet by 2030 which is supposed to be a step towards a fossil-free transport sector by 2050 [11]. To reach that level rather rapid development is needed where expanded production and use of biofuels for transportation could be an important part of the solution. Such changes would require involvement of many actors on different levels, from an "international policy arena" to the local level. This paper gives insight into whether biofuels for road transport can play an important role in the Swedish county of Östergötland in the year 2030. The aim of the study was to assess the feedstock potential for production of different types of biofuels for road transport with a resource-focused approach.

\section{Assessments of biofuel potentials}

Many initiatives have been taken to assess biofuel (or bioenergy) potentials, to gain knowledge about the extent to which biofuels can provide solutions for human energy demand. In scientific literature, there are many studies covering large geographic areas, with a global or extensive regional scope (where a region e.g. can be a large part of a continent). Such studies can be characterized as highly aggregated and conducted on an overarching level or a high level of abstraction. They provide valuable input about the boundaries of bioenergy strategies. The majority of the biofuel potential studies are long term, often with a time span until the year 2050 or 2100. Many studies focus on energy crop potentials retrieved from surplus agricultural land [12]. Short-term or mid-term perspectives (2020-2030) are less represented (ibid.). It is also less common to focus on a local scale and conduct more detailed studies. However, every geographic area has its own specific conditions for biofuel supply, production and demand. Moreover, feedstock with low energy density requires local solutions to reach a good energy balance $[13,14]$. The highly aggregated studies provide interesting information about energy potential, but their resolution is often far too low to give guidance concerning actual implementation, for instance when it comes to building biofuel production facilities.

The issue of scale influences national roadmaps for how each country is to reach binding targets required by the European Renewable Energy Directive (RES) [cf. 15], and the previously required biomass action plans. Kautto and Peck [16] conclude that plans for regions within a country are important to concretise national level objectives, especially in terms of mobilizing biomass resources. Further on, they observe that national plans are not constructed as a "sum of regional plans" and conclude that national level work needs to recognize directions of work at ground level if it aims at delivering a realistic picture of what can be achieved [16]. Similarly, Bagliani et al. [17] argue that adoption of renewable energy sources requires careful consideration of the local scale.

In addition to the issues of geographic and temporal boundaries, Berndes et al. [18] found in a review of 17 studies that most studies either could be categorized as demand-driven or resource-focused. Simplified, the demand-driven assessments focus on the market side, e.g., analyzing the competitiveness of biofuels or estimating the amount of feedstock required to reach certain objectives. Resource-focused assessment looked more into the supply side, e.g., considering the available amounts of feedstock.

Concerning biofuel potentials, there are several different types of potential in literature and the terminology is not always consistent [cf. 19,20,21]. Based on a short overview, it can be relevant to have the following "perspectives" in mind: 
- Geography: what area is included, which could range from a global to a local level. It seems common to only focus on land areas, i.e., to exclude seas and sometimes also inland waters. As mentioned above, a specific type of land can be selected, such as surplus agricultural land. For different types of areas, a share can be selected, e.g., a share of arable land.

- Time perspective: influencing many other aspects such as the level of policy and technical development.

- Biomass types: what type of biomass is included, where some studies have a rather broad scope (see theoretical potential as defined in Offermann et al. [12], comprising all biomass produced through photosynthetic reaction), while others only focus on some selected crops or material flows.

- Share of biomass: for the selected types of biomass it has to be decided what share to include. Here, competing needs may need to be considered, such as food production.

- Energy: there are different ways of assessing the energy potential, where some studies focus on the energy content for each feedstock while others apply a broader scope and to some extent include the use of energy in the value chain, for example, for collection, transport and production of biofuels.

- Socio-technology: taking into account what types of feedstock are suitable for biofuel production from a technical perspective. For example, for some feedstock there is mature technology available while others will require development to be utilized. The socio-technical part considers institutional and social constraints, policy incentives, etc.

- Economy: ranging from a wider socio-economic perspective to the economy for individual actors such as biofuel producers. Focusing on producers, it can be defined as the potential that can be produced at economically profitable levels. Of course, the chosen time perspective can influence this potential.

To make biofuel potential assessments relevant, transparent and easier to compare, it is important to specify choices and issues regarding the scope for these different perspectives. The choices influence how useful potential studies are concerning the possibilities for implementation. For example in line with the arguments of Bagliani et al. [17], a local, shortterm perspective considering existing facilities and technology and the economic feasibility for biofuel producers is more valuable for "implementers" than a very general study mainly comprising theoretical potentials.

\section{From biofuel feedstock potentials to implementation}

Although the estimates of biofuel potentials vary considerably [12], it can be concluded that a large share of the existing potential is not yet implemented. Seen from the perspective of a biofuel producer, Figure 1 illustrates a schematic process from assessing biofuel potentials to implementation, meaning that biofuels are produced and sold on a market. It should be emphasized that even if some feedstock categories are promising based on the first four steps, the process is far from implementation. Of course, interlinked issues concerning technology, economy, organization, policy, etc. are often decisive, indicated in the box to the right in the figure. The challenges of implementation also includes the users' dimension and key factors such as infrastructure and public acceptance mentioned by for instance Lim \& Lee [22]. Some authors also refer to the innovation gap [cf. 23] which is relevant in this study since technological innovation is required for the implementation of parts of the biofuel feedstock potential. It is worth emphasizing however that there is a great deal of support that the social dimension involving trust, relations and networking is a key factor for implementation of 
sustainable industrial practices, but often is neglected [24,25].

Study of potential

\begin{tabular}{|c|c|c|c|c|}
\hline $\begin{array}{l}\text { Area \& time } \\
\text { period: } \\
\text { available } \\
\text { biomass }\end{array}$ & $\begin{array}{l}\text { Selected } \\
\text { types of } \\
\text { biomass }\end{array}$ & $\begin{array}{l}\text { Share of } \\
\text { selected } \\
\text { types of } \\
\text { biomass }\end{array}$ & $\begin{array}{c}\text { Energy } \\
\text { potential, } \\
\text { energy carriers }\end{array}$ & $\begin{array}{l}\text { - Technology: collection, treatment, production, etc. } \\
\text {-Economics: prices for feedstock, fuels, production, etc. } \\
\text { - Networks: customers, suppliers, financers, etc. } \\
\text {-Internal organization \& resources, etc. } \\
\text { - Policy: means of control, permits, etc. }\end{array}$ \\
\hline 1 & 2 & 3 & 4 & Etc. \\
\hline
\end{tabular}

Figure 1. A schematic sketch of the process from the assessment of biofuel potential to implementation, from the biofuel producer perspective.

\section{Resource efficiency}

Biofuel production is expected to increase in Europe due to the push for renewable energy in policy frameworks, but the regulation also requires reduced climate impact and other types of environmental improvements [26]. Some biofuel production systems have rightfully been criticized from an environmental perspective and it is important to bear in mind that the environmental performance can vary greatly. For example, Börjesson [27] has shown that depending on the land on which the feedstock for ethanol is produced, how the conversion process is designed and which calculation method is used, the difference in GHG emissions compared to petrol could vary from +350 to $-80 \%$. Martin \& Eklund [28] also show how environmental performance of biofuels is influenced significantly both by local conditions for production as well as by the choice of system boundaries and the allocation of environmental pressure to by-products.

To reach the referenced objectives within the EU and Sweden, it is crucial to establish resource-efficient biofuel production solutions. One important aspect to consider regarding resource efficiency is to what degree biofuel production is integrated with other sectors regarding feedstocks, energy supply and by-products. In this article the term synergistic is used to describe this varying degree [cf. 29,30]. For example, the common centralized largescale production systems demanding huge amounts of feedstock from monoculture agricultural practices [31] cannot be seen as synergistic but rather linear. This is because they typically convert one or a few primary raw materials to one fuel, using substantial amounts of fossil-based energy and not having much focus on adding value to by-products. Such linear systems often lack adaptive capacity important for resilience and are therefore more vulnerable to price fluctuations in primary raw materials [32]. A focus on energy security in combination with the attempt to utilize the economy of scale are drivers behind this development, which to some extent also might be a result of that climate change objectives historically have been neglected in the development of biofuel policy [33]. Recent development of policy frameworks like the European RES Directive and the American Renewable Fuels Standard (RFS) amended by the Energy Independence and Security Act of 2007 has though resulted in incorporation of GHG emission reduction objectives which are assumed to contribute to the development of more resource-efficient production systems for biofuels with better environmental performance. The synergistic model involves more actors, often within geographic proximity which increases connectance [cf. 34]. Such production systems can utilize larger number of raw materials including by-products and are able to produce several products instead of one, preferably also more valuable products. Synergistic production systems could also involve energy with lower exergy (e.g. waste heat from another industry instead of heat from a fossil fuel boiler) and large share of renewable energy inputs. Hardy \& Graedel, focusing on industrial systems in general, argue that it is not the number of links, but the symbiotic utilization of the links that is the crucial parameter for connectance 
[34]. In Östergötland, Sweden, the Händelö industrial area is an example of a synergistic production system [35] involving biofuels to a large extent. Figure 2 illustrates schematically a linear (biofuel) production system and a more synergistic one.

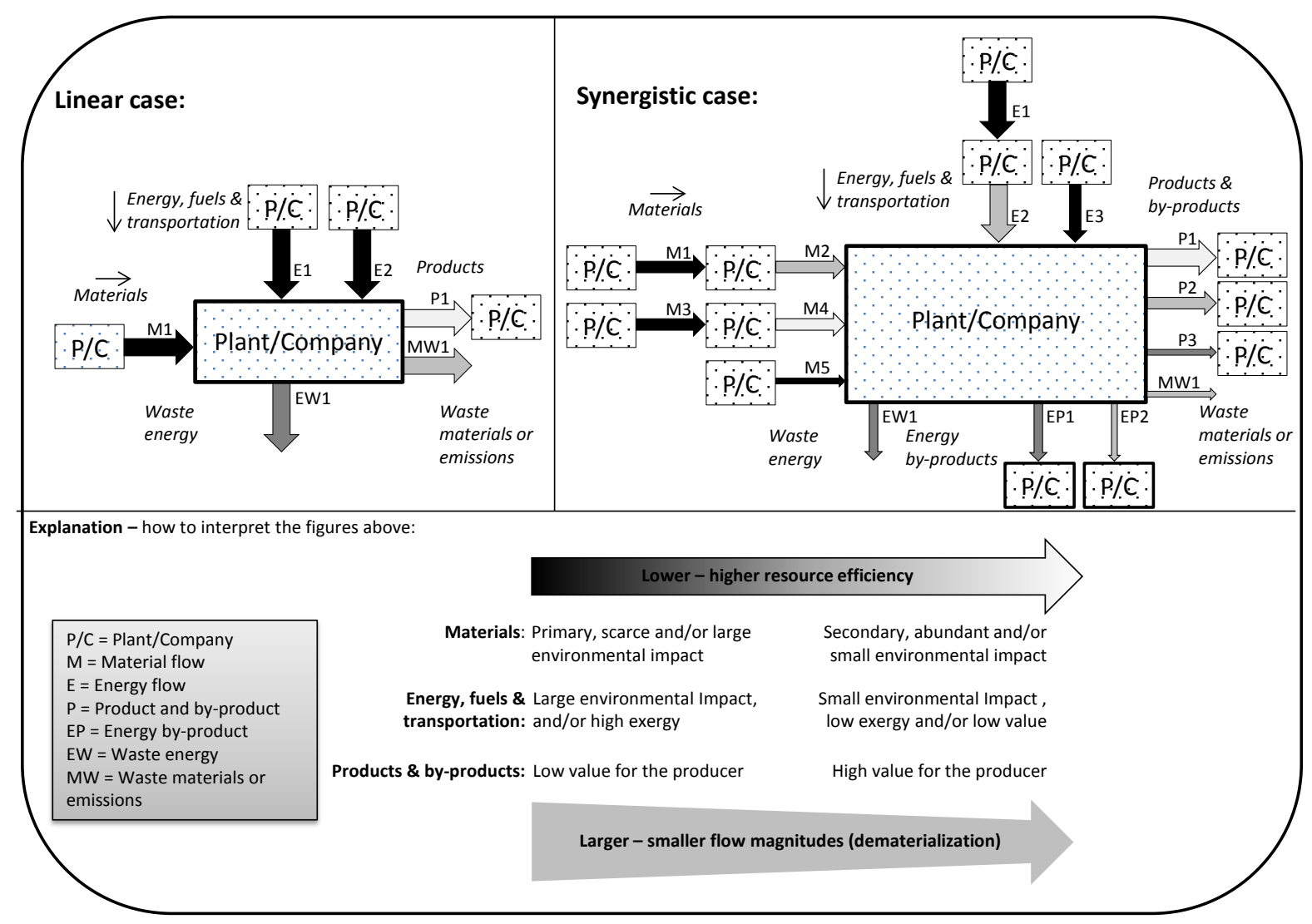

Figure 2. Illustration of a linear production system in contrast to a more synergistic example. The figure is only intended to roughly illustrate important differences, focusing on the main plant/company in the center for each case. For other plants/companies (P/C) only the flows related to the main plant/company are shown (Adapted from Ammenberg et al.[29]).

\section{Aim and scope}

The main aim of this study is to assess the feedstock potential for production of biofuels for road transport, in the county of Östergötland, Sweden. An additional aim is to more generally contribute to knowledge on how to carry out similar assessments. The present situation is considered, but an important purpose is to assess the potential for the year 2030. This means that in comparison with common approaches, this study has a rather local and short-term perspective, with a bottom-up perspective considering local conditions. The timeframe was chosen to match well with time periods considered in political goal processes at the municipal and county administrative levels.

To assess the future biofuel potential, two resource based scenarios have been used, meaning that this paper is mostly focused on step 1-4 in Figure 1. It also to some extent considers technological development and economic constraints, i.e., moves beyond step 4. However, it should be emphasized that many of the decisive contextual factors to the right in the figure have not been in focus. To assess the climate impact of the different scenarios a rough estimation was used for comparison with a petroleum based scenario. 
Investments in biofuel production facilities are an essential bottleneck when it comes to implementation since capital costs are significant in economic assessments of biofuel development [36,37]. Therefore an overall estimation has been made to roughly assess what is required in terms of production plants to realize some of the potential, based on existing typical plants and/or information about plausible plants to be built in the near future.

\section{Methodology}

The methodology section is divided into several subsections providing information about the studied region, and how the biofuel potential, the two different scenarios and the need for biofuel production facilities were assessed.

\section{The Swedish and Östergötland context}

Sweden is a leading country in renewable energy, but faces great challenges to reach ambitious objectives regarding biofuels in the transport sector. Östergötland is considered a leading-edge county within Sweden [38]. In the county there is large scale, synergistic and mainly locally supplied production facilities for biofuels for transport [cf. 28]. An important part is the industrial symbiosis network at Händelö outside Norrköping that includes an ethanol plant, a biogas plant and a biofuelled CHP plant which are important parts of a cooperating cluster, also involving forestry, recycling and other industrial sectors. In Linköping, with a third of the county's inhabitants, there is also a biofuel production system that is integrated with several other sectors, involving a waste incineration CHP plant as well as the agriculture and food sectors. The CHP plant is operated by a municipally owned waste handling company. The current production of biogas as a transport fuel covers about $6 \%$ of the present fuel market in Linköping.

The county of Östergötland has an area of 10,605 square kilometres and a population of 430,000 inhabitants in 2010, expected to increase to about 458,000 by the year 2030 [39]. Population density is about 41 persons per square kilometre, which is a fairly high figure for Sweden but a low figure for Europe. Östergötland is a markedly agricultural county, but forest and bodies of water like the Baltic Sea and freshwater lakes of various sizes are also characteristic. An argument often heard is that there will not be space enough to grow both food and feedstock for biofuels and that countries like Sweden have an advantage because of low population density. However the climate means short growing seasons (approximately 200 days in southern Sweden [40]), implying that other areas in the world that are more densely populated may still have similar possibilities to utilize biofuels for transportation if their conditions for biomass growth are more advantageous [cf. 41].

The characteristics of the Swedish energy system influence the conditions for biofuel production. Around 1980 a transformation of the Swedish heating and cooling sector began, involving a larger share of renewables [42]. This development has been ongoing and in 2011 almost 32\% of the final domestic energy use in Sweden came from biofuels, exceeding the corresponding figure for oil (30\%) [102], a large part of which is used in the transportation sector representing one quarter of final domestic energy use [43]. Solid biofuels and waste have become increasingly important as feedstock to CHP plants connected to district heating networks. This solution has led to significant improvements in energy efficiency. In total 48\% of Swedish final domestic energy use in 2011 was renewable [10]. The large share of early investments in hydroelectric and nuclear power as well as an industrial structure of electricityintensive industry generates low electricity prices compared to many other countries in Europe. Incentives for electricity production from biogas systems are thus weak in comparison to upgrading of biogas for transports, which often pays better. 


\section{Feedstock categories, choices and data collection}

The methodology follows the general idea illustrated in Figure 1. However, specifying the content in this study leads to Figure 3.

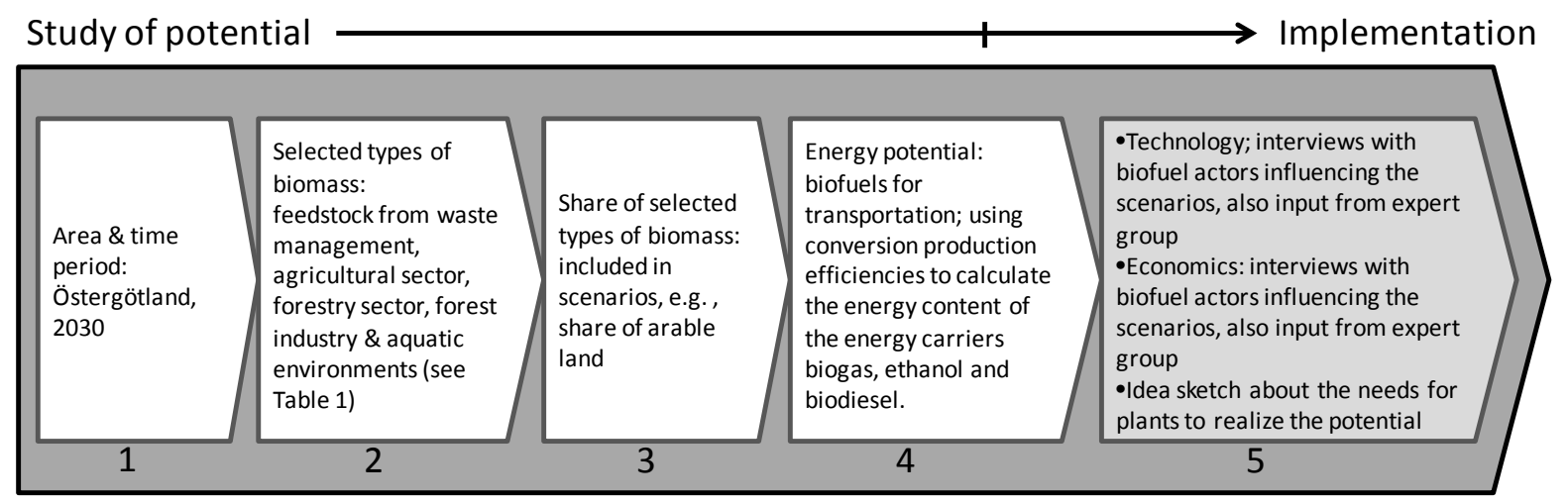

Figure 3. The main steps of the methodology employed in this study, related to the more general process in Figure 1.

The main supplying sectors included were the waste sector, the agricultural sector, the forestry sector, and aquatic environments, following the approach applied by Cherubini (2010) [44]. Within these four sectors, different feedstock categories were included depending on their relevance concerning the biofuel potential for 2030 (Table 1). This selection was based on literature and the authors' knowledge, but to complement this approach with a bottom-up perspective, an interview study was carried out involving seven persons having knowledge and experience of biofuels. They represented academic and public organizations as well as companies that are actively involved in the biofuels sector [45]. Semi-structured interviews provided information for the selection of feedstock categories, leading to some adjustments of earlier assumptions. The respondents also gave valuable information that was used to estimate the amount for some feedstock categories and validate data from literature.

Materials from the agricultural and waste sectors are already used for biofuel production to quite a large extent, while it is less common to use feedstock from forestry and uncommon to use feedstock from aquatic environments. Algae from the sea is often not included in assessments of biofuel potential, but is included in this study since it is a feedstock assumed to be able to phase in step by step in the existing biogas production system due to the flexibility of biogas technology [46]. The potential of cultivated microalgae for production of biofuels and other valuable products has gained more interest in energy scenarios as well as for the biorefinery concept [47]. However algae from the sea is an example of what the authors define as multi-functional feedstock, where development also could be driven for example by the wish to reduce eutrophication problems in the Baltic Sea. This contributed to the choice to include 'algae' (natural/'wild' macro algae and seaweed, i.e. not cultivated algae) from the sea as feedstock in this study. 
Table 1. Feedstock categories included in the study.

\begin{tabular}{|l|l|l|c|}
\hline Waste management & $\begin{array}{c}\text { Agricultural } \\
\text { sector }\end{array}$ & $\begin{array}{c}\text { Forestry sector, forest } \\
\text { industry }\end{array}$ & $\begin{array}{c}\text { Aquatic } \\
\text { environments }\end{array}$ \\
\hline Sludge from sewage treatment & Manure & $\begin{array}{l}\text { Process water from pulp } \\
\text { and paper industry }\end{array}$ & Reed \\
\hline Food industry by-products & $\begin{array}{l}\text { Agricultural } \\
\text { waste }\end{array}$ & Tall oil & $\begin{array}{c}\text { Algae, from } \\
\text { ocean }\end{array}$ \\
\hline $\begin{array}{l}\text { Food waste (households, canteen } \\
\text { and restaurant) }\end{array}$ & Grains & & $\begin{array}{l}\text { Farmed } \\
\text { mussels }\end{array}$ \\
\hline Used Cooking Oils (UCO) & Stillage & & \\
\hline Park and garden waste & Ley & & \\
\hline Landfills & Straw & & \\
\hline Slaughterhouse waste & & & \\
\hline
\end{tabular}

One important decision in the selection of feedstock was to exclude lignocellulose biomass from forests. This could be questioned since there are expectations regarding forest industry developing into biorefineries producing also biofuels. This is certainly one possible trajectory but progress in this direction is still modest [48] and it has been observed that the forest cluster in Scandinavia is fairly passive in relation to what would be needed if biorefinery concepts are to be realized [49]. It is not possible to predict what is going to happen regarding this development but the point of departure in this study excludes this potentially large feedstock, which was also in line with the views of the respondents. However, lignocellulose material such as straw was included in the study. Other important assumptions concerned characteristics of different types of feedstock, conversion paths and their efficiency.

Considering the feedstock categories in Table 1, choices by the research team were especially important for the agricultural sector, since the selection of crops has a big impact on the results. Perennial crops are often supported by biofuel research due to their multifunctionality. A review article by Xie et al. [50] indicates that by selecting perennial grasses for bioenergy production in the U.S. and Europe many benefits could be achieved at the same time, such as ecological services in agricultural production systems, a landscape management element function and habitat creation for different animal species. The use of ley crops therefore became important in this study.

In the third step in Figure 3, the share of each feedstock that could be used for biofuel production is decided. For dedicated biofuel crops this is dependent on how much arable land could be used. At present, about $15 \%$ is used, mainly to grow grain for ethanol production. Before fossil energy-fuelled agriculture, it is estimated that approximately $30 \%$ of the arable land was used to feed animals for transport and draft [51]. We assumed 30\% and $22.5 \%$ of the arable land could be used in our scenarios. To further analyze the demand for arable land today it can be noted that the population increase of Östergötland between 1900 and 2030 is estimated to 70\% [39], while modern agricultural practices resulted in a doubled yield concerning cereals and other annual crops since the 1940s [52]. The diet and food consumption of the population has changed during this time period, but according to GerbensLeenes [53] the corresponding land requirements for food production in the Netherlands has not increased between 1950 and 1990. Gerbens-Leenes also give an approximate land requirement per capita for different countries in Europe based on a general national diet which for Swedes was estimated at 0.19 ha per capita and year [54]. Hence, approximately $42 \%$ of the available arable land would be needed for food security in 2030 if the population size in Östergötland is assumed to be 458000 [39] and the total area of arable land is assumed to be 204303 ha [103]. Using 22.5\% and 30\% respectively of the arable land for biofuel production in the scenarios in 2030 would then not be a threat to food security in Östergötland. However, 
the risk for land use conflicts is always difficult to analyze in geographically small regions since there is often no obligation for regions to be self-sufficient in the production of food and fodder.

Multiple data collection methods were used to gather information about each type of feedstock, including the interviews mentioned. Most of the data was found in so-called grey literature, such as national reports from authorities, NGOs, research institutes, companies, international organizations and in legislative documents. Some information came from scientific articles. In addition, consultation with experts from industry and academia were necessary when relevant information was not found in literature. A major part of the data concerns the time period around the year 2010 [cf. 45]. However, for the important feedstock categories the assumptions and choices had more impact on the result of the assessment than the actual year studied (see appendix for assumptions made in the assessment). For example, as the amount of ley was calculated based on a certain share of the available arable land, and since the size of this land use changes slowly, the share of ley is not affected so much by the chosen year. Other feedstock categories can vary a bit more over time, such as the amount of tall oil since it was derived from the production at a paper mill.

The fourth step in Figure 3 is about assessing the energy potential, where the energy content of each feedstock has been calculated. Conversion production efficiencies have been used to calculate the energy content for each energy carrier, converting primary biomass into secondary energy carriers. Consequently, the focus in this step is on the amount of biofuels for transportation that can be produced, not considering their energy balance from "cradle to gate,” i.e., not including the energy needed for production (agriculture, forestry), collection, pretreatment, industrial biofuel production processes, etc. For each selected feedstock category it was decided which biofuel seemed most reasonable to produce, whether ethanol, biodiesel or biogas. However, the environmental performance as well as energy performance has to be considered in relation to the choice of energy carrier, hence the climate impact was assessed for the scenarios which is further described in the next section. Concerning the different biofuels it could also be noted that in this study both HVO (Hydrotreated Vegetable Oil), which currently mainly is represented by tall oil in Sweden [55], and FAME (Fatty Acid Methyl Ester) are referred to as biodiesel.

The characteristics of the feedstock give guidance on which biofuel to produce. Cherubini [44] groups biomass feedstock in three broad categories: carbohydrates and lignin, triglycerides and mixed organic residues from a certain feedstock. Ethanol requires carbohydrates or lignin, biodiesel requires triglycerides while biogas can be produced from both these hydrocarbons as well as proteins, meaning that biogas is a possible choice for all feedstock categories. Several of the included feedstock categories contain substantial shares of carbohydrates and lipids. Therefore, an option would be to produce all three biofuels from the same feedstock. However, such combinations have not been considered except in the case of the already existing ethanol production plant, where the by-product of thin stillage is used to produce biogas.

Comparing the three selected biofuels, the land use efficiency for biogas production is higher due to the non-specificity regarding feedstock described above, but also because the whole crop can be used, not only the starchy or oil-rich parts. Biogas production based on energy crops have the potential to generate about twice the net energy yield per hectare per year compared to wheat ethanol or rape seed biodiesel [46]. The land use efficiency of ley for biogas production contributed to the choice of ley as a dedicated energy crop in this study, but 
also important was that perennial ley has the potential to bring other benefits to agricultural areas such as improved soil and water quality [56]. If only land use efficiency is considered there are other crops though that would have performed even better measured as biogas production per area of land, e.g. sugar beets.

In this study, biogas was generally chosen before other biofuels due to resource efficiency. However, existing plants, vehicles and infrastructure also have to be taken into consideration. Because of the existing ethanol plant, the choice was to continue to produce ethanol from wheat and ethanol was also considered as a reasonable choice for the straw feedstock assessed.

\section{Scenarios}

It is uncertain how the conditions for biofuel production and use will develop during the time period until the year 2030. In this study, two scenarios were developed from the present situation. Differences between the scenarios were determined by the availability of resources (feedstock), technological aspects and, to some extent, economic constraints. Thus, the construction of the scenarios was influenced also by some decisive parameters in the right box in Figure 1.

The first scenario was called the EXPAN scenario, mainly implying an expansion in line with the present direction of development until 2030. It comprised improved control, distribution and usage of important material flows within the agricultural and waste sectors, leading to a better availability of raw materials for biofuel production. However, technological progress was assumed, but only technical solutions that the authors and interviewees judged as being close to implementation. The second scenario assumed larger progress in technological innovation (INNTEC). For some feedstock (ley, algae and manure), different exploitation shares were assumed for different scenarios (see appendix for assumptions made in the assessment).

The technology for biogas production from ley crop is already well known $[57,58]$, hence the uncertainties are instead mainly coupled to parameters like agricultural policy, the global price development of agricultural products and environmental policies [59]. The share of arable land used for biofuels was set at 30\%. Existing wheat cultivation for ethanol production covers $15 \%$ and was assumed not to change. The additional share of arable land dedicated for cropping biofuel feedstock was assumed to be used for ley. EXPAN scenario includes $50 \%$ implementation of the ley potential and INNTEC 100\%. The regional total of about 12,500 ha in 2010 (about 40\% of the need for the INNTEC scenario) in fallow land indicates that conflicts with other land use are moderate.

Technology for using algae as feedstock for biogas is assumed to be close to implementation, but technical issues related to the collection of algae offshore [60,61], where the big potential is found, and the dewatering step prior to feeding a biogas digester with algae are the reasons for including only $10 \%$ of the algae potential in the EXPAN scenario and $90 \%$ in the INNTEC scenario.

The biogas potential of 54 GWh from manure refers to a study made by Swedish Biogas International in 2008 [62]. This energy potential was obtained through the finding that $20 \%$ of the manure in Östergötland could be found in "hot spots" of animal farming, i.e. areas where enough manure was produced to enable economically viable biogas production. 
A simplified assessment of GHG emissions was made for the EXPAN and INNTEC scenarios. Rough assessments were performed using typical GHG emission savings for particular biofuel production pathways given in Annex V part A and B in the EU RES Directive [see 15]. For biofuel production pathways not included in Annex V part A and B (some of the biogas feedstock) a general figure for GHG emission savings on $80 \%$ was used except for biogas from ley, where 60\% GHG emission savings was assumed (see appendix for a more detailed list of assumptions made for GHG emission savings). The assessed GHG emission savings include all the emissions on a life cycle basis (from cradle to gate) compared to equivalent petrol or diesel use, except possible emissions caused by LUC (Land Use Change) and ILUC (Indirect Land Use Change). A fossil comparator figure of $83.8 \mathrm{~g} \mathrm{CO}_{2}$ eq/MJ (Annex V, EU RES Directive [15]) was used for the calculation of the GHG reduction for the scenarios compared to if only fossil fuels had been used.

\section{Production plants to realize part of the potential}

The scenarios provided information about the biofuel potential in terms of energy. The need for production plants to realize the potential was estimated, since investment in plants is a bottleneck. A smaller part of the feedstock potential can probably be utilized within existing facilities, but the major part of the feedstock potential included in the scenarios requires new plants, including new technology. Therefore a sketch of the need for production plants was created, including what type of plants might be needed and where they could be located.

The need for production plants was based on the feedstock categories in the EXPAN scenario except for (i) those already used in existing plants (see Figure 4); (ii) landfill - only a smaller unit for collection and cleaning is needed; (iii) tall oil - a production plant with capacity to take care of it already exists in another region; (iv) sewage treatment - all sewage treatment facilities included in the EXPAN scenario have digestion chambers, but no biogas upgrading equipment, which implies that only a smaller unit for collection and cleaning is needed .

The type and size of the plants for the conceptual sketch were chosen based on knowledge about existing plants and technology, or solutions expected to be implemented in the near future. A balance between economy of scale and location in proximity to the feedstock was sought in the sketch. Biogas solutions require short transportation distances for the feedstock due to high water content per energy unit. Similarly, the water/nutrient ratio also limits the transportation distances of the biofertilizer [13]. The energy balance for biogas from manure turns negative when the transport distance exceeds $200 \mathrm{~km}$ since the biogas yield of the raw material is low and the transport of the digestate is increasingly energy demanding as the distance between the biogas plant and the farm increases (ibid.).

Normal transportation distances for feedstock (manure, harvest residues, energy crops, slaughterhouse residues) is often assumed not to be longer than $15 \mathrm{~km}$ while an average distance of $10 \mathrm{~km}$ is sometimes used [13,14]. The establishment of small-sized plants is therefore suggested for manure and algae close to the feedstock. For household waste and ley, medium to large-scale plants close to the market for the products is suggested instead, since they can bear a little more transport and therefore have greater potential to benefit from economy of scale. For energy crop plants of $300 \mathrm{GWh} /$ year, the average transportation distance could be $24 \mathrm{~km}$, while examples of even bigger biogas plants in Germany (450 $\mathrm{GWh}$ /year) sometimes have catchment areas with radius of up to $40-\mathrm{km}[14,63]$. Berglund and Börjesson [13] found that for municipal organic waste and slaughterhouse waste the transport distance could be up to approximately 580 and $750 \mathrm{~km}$, respectively, before the energy balance turns negative. 


\section{Results}

\section{Biofuel potential in Östergötland}

At present, the production of biofuel for transport in the region of Östergötland generates fuel corresponding to almost $500 \mathrm{GWh} /$ year (Figure 4). However, only a small part of it is used within the region, since 92\% is ethanol used for low blending of petrol, mainly in Sweden. The remaining $8 \%$ is biogas, mainly used within the region. The EXPAN scenario reaches an energy potential of almost $1300 \mathrm{GWh} /$ year and INNTEC almost $2100 \mathrm{GWh} /$ year.

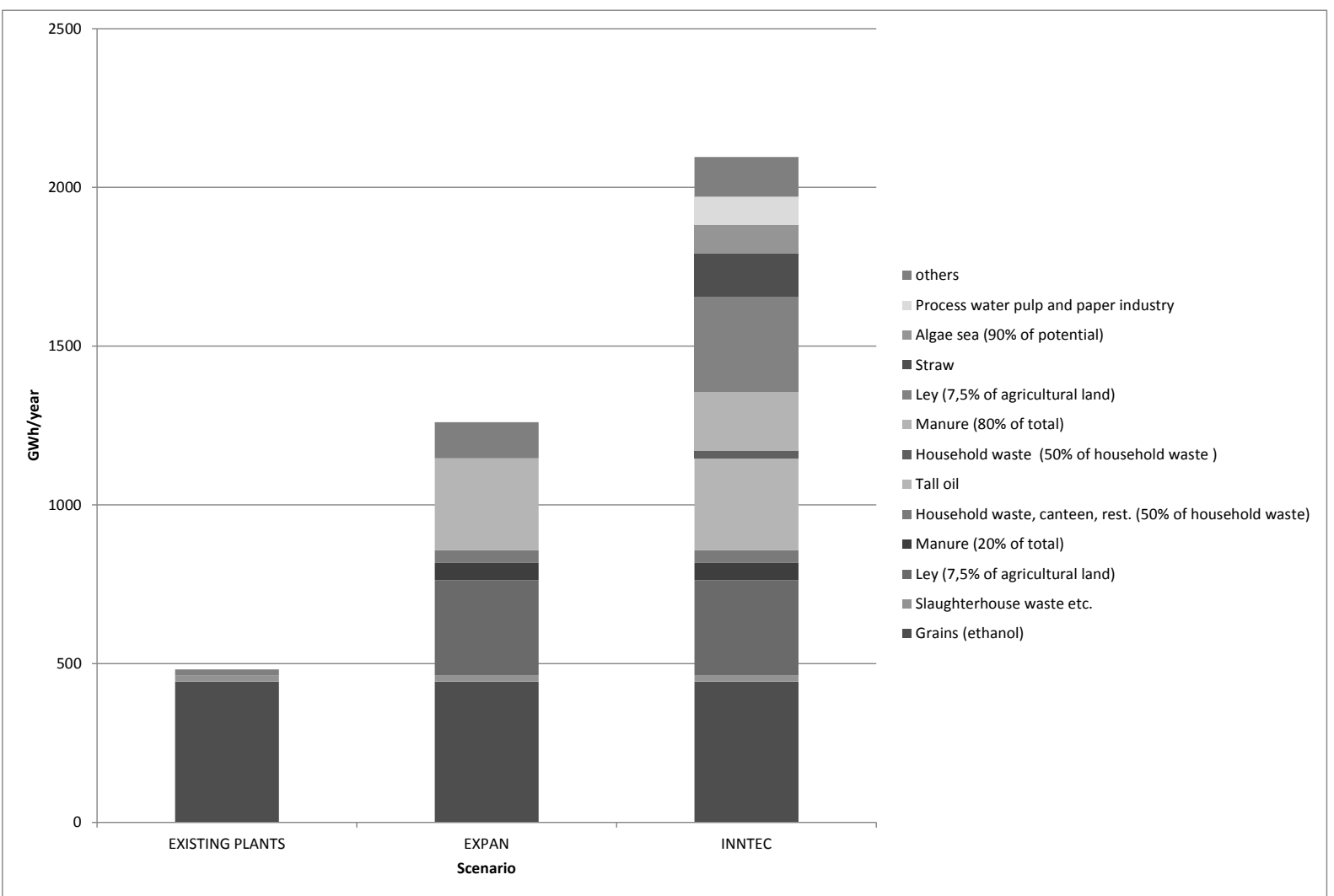

Figure 4. Energy potential for EXPAN and INNTEC scenarios. Some potentials are divided into the EXPAN and INNTEC scenario since it is assumed that the technology/cost required to utilze them differs. An example is household waste where a common self sorting rate is $50 \%$, but for which it is assumed that the remaining 50\% could also be used with innovative collection technology and therefore it is included in the INNTEC scenario. "Others" in the EXPAN scenario include thin stillage, used cooking oil, agricultural waste, industrial food waste, sewage treatment (optimized digestion), landfill, sea algae (10\% of potential), reed from the coast, park and garden waste (dry digestion) while "others" for INNTEC also includes sewage treatment (50\% of total) and farmed mussels.

The energy demand for road transport in the region in the year 2030 is assumed to be 4000 GWh/year, which is the present value which is assumed to be stable during the period [45]. This means that a development in line with the EXPAN scenario can cover up to $30 \%$ of the need while INNTEC can provide about $50 \%$ of it.

Two of the feedstock categories, ley and tall oil, contribute significantly more to the EXPAN scenario than other feedstock why it is interesting to look at to what extent they can influence the biofuel potentials. The ley potential depends on how much arable land that can be used for bioenergy production which means that this potential can both increase as well as decrease. 
Due to the reliance on the pulp production where a fixed share of tall oil is produced, the tall oil potential was assumed to be stable or decrease. Based on these assumptions the ley potential could reduce the EXPAN potential up to $24 \%$ or increase it in relation to available additional land, while the tall oil potential could reduce the EXPAN potential up to 23\%.

The increase of biofuels in the EXPAN scenario depends mainly on biogas which would constitute $42 \%$, where ethanol represents $35 \%$ and biodiesel $23 \%$ of the biofuel production. In the INNTEC scenario the share of biogas is $59 \%$, where the figures for ethanol and biodiesel are $28 \%$ and $14 \%$ respectively.

\section{Conceptual sketch of new biofuel plants}

The new feedstock categories in the EXPAN scenario form the basis for a number of new biogas plants (Table 2). With the establishment of about 25 biogas plants of different types and sizes up to $463 \mathrm{GWh} /$ year of biogas could be produced in the year 2030 (see Table 2).

Table 2. Biofuel production plants needed to realize $463 \mathrm{GWh} /$ year of biogas. This includes all feedstock categories in the EXPAN scenario except the ones already used and tall oil.

\begin{tabular}{|c|c|c|c|}
\hline Feedstock & Type of plant & $\begin{array}{l}\text { Energy } \\
\text { potential } \\
\text { (GWh) }\end{array}$ & Number of plants \\
\hline $\begin{array}{l}\text { Ley }(7.5 \%) / \text { Tops, sorted out } \\
\text { potatoes etc./Stillage }\end{array}$ & Biogas & 331 & 6 \\
\hline Manure (20\%) & Biogas (farm plants) & 54 & 11 \\
\hline $\begin{array}{l}\text { Household waste, } \\
\text { canteen/restaurant, } \\
\text { Industrial food waste } \\
\text { (potential) }\end{array}$ & $\begin{array}{l}\text { Biogas co-digestion } \\
\text { (hygienization) }\end{array}$ & 54 & 2 \\
\hline Algae sea (10\%)/Reed coast & Biogas & 11 & 2 \\
\hline Park and garden waste & Biogas (dry digestion) & 13 & 4 \\
\hline Total & & 463 & 25 \\
\hline
\end{tabular}

The biggest potential is ley as a dedicated crop where $300 \mathrm{GWh}$ /year potentially could be produced in 6 large-scale biogas plants. Some of them would probably benefit from some kind of co-digestion with smaller amounts of other agricultural waste or feedstock found locally like tops, poor quality potatoes and grains or other feedstock where the availability varies over time. It was assumed that this potential would contribute an additional 31 GWh/year at the "ley plants".

Eleven farm-scale plants together could contribute about $54 \mathrm{GWh} /$ year from manure. The low energy content of manure means that it needs to be utilized close to the farms where it was produced. Many farms are too small to have their own biogas plant and are also situated too far away for cooperation around a plant, which was the reason to include only $20 \%$ of the manure potential in the plant sketch. Household waste and industrial food waste were also estimated to have a potential of $54 \mathrm{GWh}$ /year together that was assumed to be able to realize with two new co-digestion biogas plants. For this type of co-digestion plant hygienization of the feedstock is needed which increases the costs both regarding the establishment of the facility as well as production costs.

In the EXPAN scenario it was assumed that about $10 \mathrm{GWh}$ of biogas could be produced from algae harvested in the Baltic Sea (see appendix). If this algae potential is co-digested with the smaller reed potential around $11 \mathrm{GWh} /$ year could be produced in two biogas production plants. The plants have to be located in the proximity of ports to minimize land transport since 
fresh algae have high water content in relation to energy content. Around $13 \mathrm{GWh} /$ year of biogas was assumed to be able to produce through dry digestion of park and garden waste with the establishment of four different plants.

The conceptual sketch of production plants is based on the knowledge and technology for biogas production available locally today. In some cases the technology is well documented, for instance in Germany [63]. Different feedstock needs different solutions in terms of scale, technology and location, which we have considered. For several of the feedstock co-digestion has been shown to be advantageous, but in this study we have not focused on matching optimal feedstock for such plants because this needs more in-depth study. The plant sketch should therefore be regarded as only one of several ways to realize a production of 463 GWh/year in the county of Östergötland by the year 2030.

\section{Environmental performance, focusing on climate impact}

In the INNTEC and the EXPAN scenario biofuels were found to have the potential to substitute a maximum of about $50 \%$ and $30 \%$ respectively, of the energy need assumed for road transportation in 2030 in Östergötland. If the rest of the energy need is assumed to be covered by fossil fuels the GHG emission saving for the INNTEC scenario is estimated to $39 \%$ and the corresponding figure for the EXPAN scenario is 23\% (Figure 5).

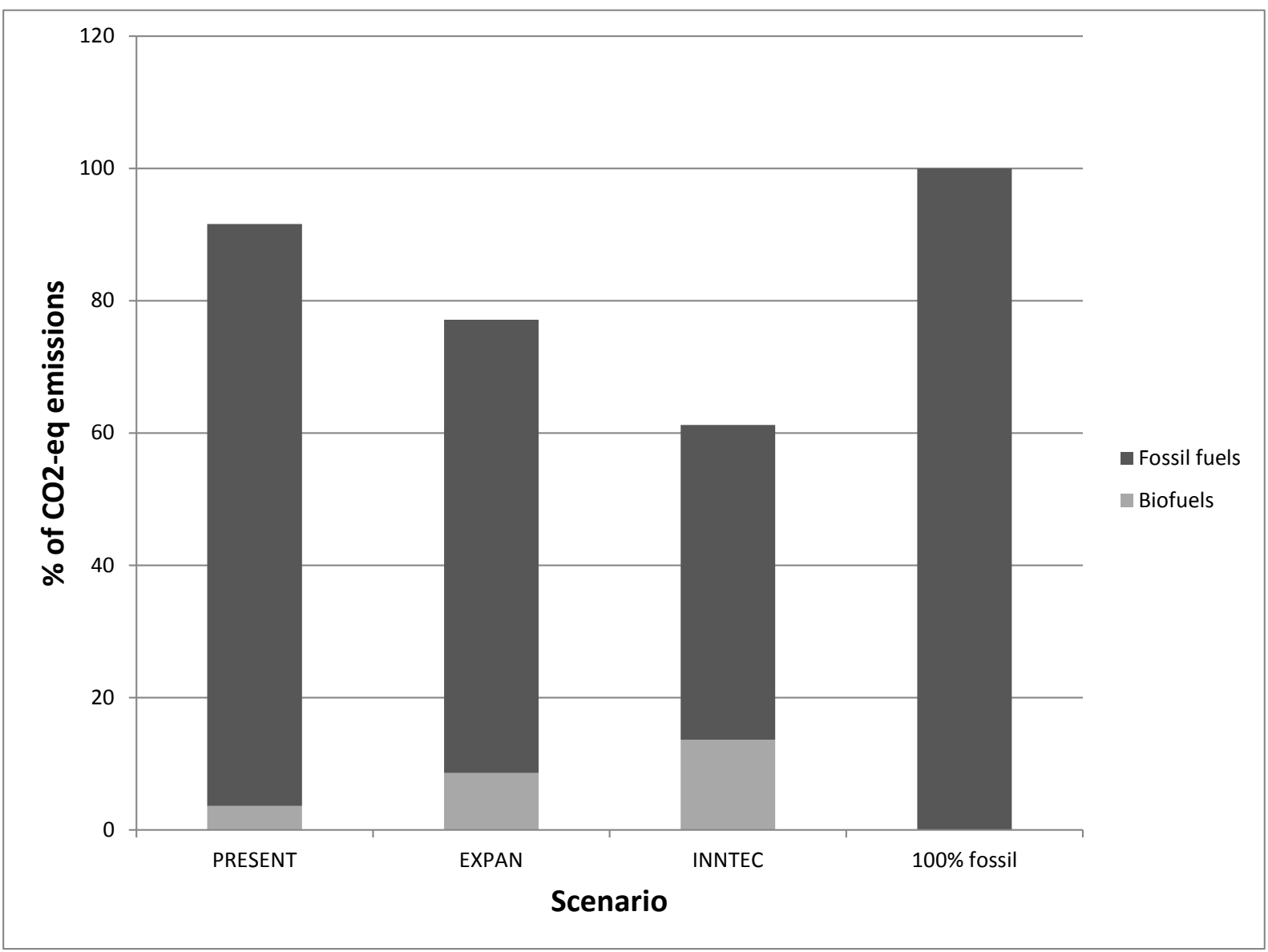

Figure 5. The biofuel and fossil fuel shares of $\mathrm{CO}_{2}$-eq emissions for the present, EXPAN and INNTEC scenarios compared to a $100 \%$ fossil based scenario used as reference.

It could be noted that the GHG emission savings for typical biofuel pathways in Annex V part $A$ and B in the EU RES Directive used in the simplified climate impact assessment performed 
have been criticized [cf. 2], e.g. because they do not include emissions caused by ILUC and too low a figure for $\mathrm{N}_{2} \mathrm{O}$ emissions for current cultivation methods of biofuels [cf. 64].

\section{Concluding discussion}

The discussion below summarizes methodological issues and to what extent biofuels can serve as a substitute for fossil fuels in the road transportation sector in Östergötland in 2030, as well as how a resource-efficient biofuel production system can develop. The challenges regarding the implementation of such systems of the scale assessed in the potential are also touched upon to identify future research needs.

\section{Methodological reflections}

As concluded in the introduction, there are many different studies assessing biofuel potentials, applying different methodologies, focusing on different types of potentials and often covering large regions with a long term perspective. In addition to results about the studied case it is interesting to reflect upon the approach and methodology from a more general perspective.

The methodology presented in Figure 1 has been useful and its general and systematic character means that it can be applied in similar studies, both local ones and in those covering larger areas. Assessments of this type are, for example, interesting for both biofuel producers and policymakers. However, it is important to notice that they involve a large number of assumptions and choices that can have a major impact on the results, and it is a big challenge to make such assessments transparent, repeatable and comparable, especially in the format of a scientific article. One way to reduce this problem, and to clarify important dynamics, is to involve interested parties in the process and discuss different options and their impact.

There seem to be a need for additional studies of similar character, i.e., with a local, bottomup and short-term perspective. Such approaches make it possible to consider existing feedstock, flows, energy systems, industrial facilities, actors, etc., and thus to deal with more integrated solutions being a part of the existing society and contributing with positive societal synergies, which is further developed in the coming sections.

\section{Biofuels for transport - potential}

The renewable feedstock in the county of Östergötland could provide biofuels corresponding to about half of the energy need for transport assumed for 2030 (4000 GWh/year) in the INNTEC scenario and about 30\% in the EXPAN scenario, without including lignocellulose material from forestry and using at maximum $30 \%$ of the arable land area. The rough assessment of the environmental performance shows that a net reduction of GHG emissions of $23 \%$ could be reached in the EXPAN scenario and 39\% in the INNTEC scenario.

The implementation of these scenarios would require an influence on distribution of important material flows within the agricultural and waste sectors. Some of the added feedstock can be utilized within the existing plants, but several new plants need to be built to realize the EXPAN potential. The EXPAN scenario assumes some minor technological progress while the INNTEC scenario included more far-reaching technological advances, from the production of raw materials to the biofuel production plants, thereby allowing a broadened range of possible feedstock. The potential in these two scenarios is of the same magnitude as an assessment study of biogas potential from domestic feedstock made by Avfall Sverige [65] where the biogas potential in Östergötland was about $1200 \mathrm{GWh} /$ year without including feedstock from forestry. 
Assumptions regarding ley have major influence on the scenarios. The ley potential could be both increased and decreased depending on how much arable land is assumed for bioenergy production. The area of arable land in fallow almost covers the land need in the EXPAN scenario. Share of fallow land varies over time due for instance agricultural policy and the European Common Agricultural Policy (CAP), in which incentives until recently was designed to reduce agricultural production [66]. The share of fallow arable land in Sweden has decreased, but still there are substantial areas that are fallow. A reformed CAP is due to go into effect after 2013 and will probably be crucial for how bioenergy production on arable land in Europe will develop. Expanding biofuel production from arable land beyond the dedicated area in the EXPAN scenario could lead to conflicting interests with fodder or food production. The risk for such land use conflicts is always difficult to analyze in geographically small regions since there is no obligation for regions to be self-sufficient in the production of food and fodder. Hence no analysis of the consequences of such expansion, e.g. whether for instance it could cause indirect land use change (ILUC), is made in this study.

Diversifying cropping systems by introducing ley crops may also contribute to more sustainable agricultural practices, where productivity and profitability could be maintained but balanced against environmental health [67].

\section{Integrated, efficient and multi-functional biofuel production systems}

The life-cycle of biofuels is very different from fossil fuels. Biomass, an areally distributed resource [68], is already part of our biological and social systems and an increased use of it as a source for biofuel production will affect these systems. This requires another perception than the one relevant for fossil fuels, a resource of punctiform distribution. The biofuel systems tend to have the characteristics of dynamic network structures, in contrast to the static tree structures that often have been the case of fossil systems. Biofuels can be produced in more sustainable ways or in less sustainable ways and since biofuels are supposed to strengthen sustainability we emphasize integrated and synergistic solutions of biofuel production systems in this study. For example, it is suggested that the same agricultural areas can provide both food/fodder and feedstock for biofuel. With this integrated approach, biofuels can contribute to a significant share of fuel for road transport without competing with food production or other important needs and also strengthen sustainable agricultural practices through introduction of ley in crop rotations and by replacing chemical fertilizer by biofertilizer from biogas production. Expanded biofuel production will also lead to increased energy security and local employment while increased reuse of secondary products and organic waste streams could contribute to a sustainable society. Integrated systems however require coordinated interaction between many actors at different levels in the life cycle of a biofuel. This makes the management of these systems complicated and challenging for development of biofuel production. Resource-efficient production of biofuels involves many synergies that could be described in terms of multi-functionality. Since biofuel production often involves large quantities of inputs and outputs including various biomass, heat, electricity and fuels there could be many synergistic collaboration opportunities [cf. 69]. Using the theories, or operational principles of industrial symbiosis, these flows of material and energy can be optimized to improve the environmental performance of products [28]. This is also in line with the "bio-refinery" concept, where biofuels could be produced from by-products from the production of higher value bio-based products [44]. Another means of visualization of resource-efficient use of biomass is the "eco-pyramid" [70] stressing the correlation between the extra energetic value and the added economic value. Fuels and heat should thus primarily be produced as by-products in a system that produces higher value 
products. Biogas production for instance can improve the resource efficiency of ethanol and biodiesel production, by utilizing their by-products [46].

The focus in biofuel production so far has mainly been on the conversion potential of a certain feedstock into a certain energy carrier. External effects upstream and downstream due to the use of a certain feedstock for biofuel production have received less attention. No one wants to pay for external benefits for a third party and this will therefore not contribute to biofuel producers' economy. Using the concept of multi-functionality can clarify external effects of biofuel production. From a societal perspective these external effects from different biofuel feedstocks have to be mapped and taken into consideration when evaluating the benefits from a biofuel production system.

Multi-functionality as a concept expressing the additional environmental benefits produced from energy crop plantations has been used in biofuel literature before, for instance by Ericsson et al. [71]. Here, we refer to it as functions related to the production of feedstock but also functions stemming from the conversion process of the biofuel as well as by-product handling (Table 3). 
Table 3. The multi-functionality of the feedstock included in this study. Main product refers to the main economic contribution of the system.

\begin{tabular}{|c|c|c|c|}
\hline Feedstock & \begin{tabular}{|l} 
Main \\
product
\end{tabular} & Secondary product & Service or ecosystem service \\
\hline Grains & Ethanol & $\begin{array}{l}\text { Dried Distillers Grains with } \\
\text { Solubles (DDGS), biogas, bio- } \\
\text { fertilizer }\end{array}$ & Nutrient recycling \\
\hline Slaughterhouse waste & Biogas & Biofertilizer & $\begin{array}{l}\text { Biological waste treatment, nutrient } \\
\text { recycling }\end{array}$ \\
\hline $\begin{array}{l}\text { Sludge from sewage } \\
\text { treatment }\end{array}$ & Biogas & $\begin{array}{l}\text { Biofertilizer or construction } \\
\text { material }\end{array}$ & $\begin{array}{l}\text { Biological waste treatment, nutrient } \\
\text { recycling }\end{array}$ \\
\hline $\begin{array}{l}\text { Used cooking oils } \\
\text { (UCO) }\end{array}$ & Biodiesel & $\begin{array}{l}\text { Glycerol (for biogas production } \\
\text { or other use) }\end{array}$ & Biological waste treatment \\
\hline Ley & Biogas & Biofertilizer & $\begin{array}{l}\text { Improve the sustainability of } \\
\text { agricultural practices }\end{array}$ \\
\hline $\begin{array}{l}\text { Agricultural waste } \\
\text { excluding straw }\end{array}$ & Biogas & Biofertilizer & $\begin{array}{l}\text { Reduced GHG emissions from the } \\
\text { decomposition of agricultural by- } \\
\text { products }\end{array}$ \\
\hline Manure & Biogas & $\begin{array}{l}\text { Biofertilizer with reduced odour } \\
\text { and improved nutrient availability }\end{array}$ & $\begin{array}{l}\text { Reduced GHG emissions from storage } \\
\text { and spreading }\end{array}$ \\
\hline Industrial food waste & Biogas & Biofertilizer & $\begin{array}{l}\text { Biological waste treatment, nutrient } \\
\text { recycling }\end{array}$ \\
\hline Food waste & Biogas & Biofertilizer & $\begin{array}{l}\text { Biological waste treatment, nutrient } \\
\text { recycling }\end{array}$ \\
\hline Tall oil & Biodiesel & & $\begin{array}{l}\text { Upgraded use compared to the use as } \\
\text { heating oil }\end{array}$ \\
\hline Landfill gas & Biogas & & $\begin{array}{l}\text { Reduce methane emission to } \\
\text { atmosphere }\end{array}$ \\
\hline Algae, sea & Biogas & Biofertilizer & $\begin{array}{l}\text { Reduced eutrophication in the Baltic } \\
\text { Sea, nutrient recycling }\end{array}$ \\
\hline Reed, coast & Biogas & Biofertilizer & $\begin{array}{l}\text { Reduce eutrophication in the Baltic } \\
\text { Sea, nutrient recycling }\end{array}$ \\
\hline Park and garden waste & Biogas & Biofertilizer & $\begin{array}{l}\text { Biological waste treatment, nutrient } \\
\text { recycling }\end{array}$ \\
\hline Straw & Ethanol & Molasses, Energy production & \\
\hline $\begin{array}{l}\text { Process water, pulp } \\
\text { and paper industry }\end{array}$ & Biogas & & $\begin{array}{l}\text { Biological waste treatment, Reduced } \\
\text { electricity use for aerated cleaning }\end{array}$ \\
\hline Farmed mussels & Biogas & Biofertilizer & $\begin{array}{l}\text { Reduced eutrophication in the Baltic } \\
\text { Sea, nutrient recycling }\end{array}$ \\
\hline
\end{tabular}

The biogas production system has been prioritized in the scenarios since it provides many opportunities for multi-functionality. Reduction of greenhouse gases, particularly when liquid manure is used as feedstock ([46]; cf. [72]), the ability to produce valuable biofertilizer and solve waste management problems are valuable system benefits. However, expanded biogas production requires larger changes in infrastructure and vehicles compared to ethanol and biodiesel and the risk of methane slip in the production chain must not be neglected. The contribution to the economic performance of secondary products and ecosystem services produced in a biofuel production system varies considerably. The bio-fertilizer from biogas production is an example of a valuable product from a societal perspective as well as from an agricultural perspective but does not contribute to the economic performance of the biogas production, because today the biofertilizer is often given to farmers for free $[73,74]$. The DDGS from ethanol production on the contrary currently contributes to a large extent to the economic performance of the ethanol production. 
Some of the ecosystem services listed in Table 3 belong to what is referred to as external effects, meaning that a third party is influenced. They could be important societal services for sustainability and therefore it could be argued that economic compensation should be available. Mitigation of GHG emissions caused by substitution of fossil fuels is not included in Table 3 since it is more or less generic for all the feedstock suggested. This is also an external benefit which to some extent is compensated for by the national tax exemption for biofuels fulfilling the sustainability criteria [15].

National policy dependence is strong for biofuel development. When considering a policy incentive which prioritizes certain feedstock for biofuel production the authors suggest that the multi-functional approach should be used. National policy programs are very important for how biofuel production systems develop, which has been illustrated for the Danish biogas sector by Lybaek et al. [75]. In a study by Lantz et al. [76], analyzing incentives and barriers for biogas expansion, it was concluded that in the Swedish context and with present policy instruments biogas production for vehicle use is the most favoured alternative. This has probably influenced the development of the biogas sector in Sweden as well as the choice of feedstock.

\section{Implementation gap}

The approach in this study has been geographically limited and short term. This made it possible to take existing plants and geographical aspects into consideration. Such a bottom-up perspective could make the results more relevant from an implementation perspective. Technical and economic aspects were considered. However, analysis of conditions for implementation was not included in this study. Obviously, a major challenge is the investments in new technology and production facilities that are needed for the realization of the assessed biofuel potential. Many actors within the industry face problems of profitability leading to a focus on existing raw materials, production efficiency, etc. The increased rawmaterial potentials highlighted by this study provide opportunities in relation to economy of scale. For example, the smaller amounts of materials within the waste sector can probably be utilized within existing facilities. However, more unconventional feedstock implies additional technical challenges and the large feedstock potentials of ley, manure, household and industrial food waste, algae and park and garden waste require new production plants.

The realization of the EXPAN scenario potential would imply building 25 new biogas plants corresponding to a building capacity rate of 25 GWh per year in the county until 2030. However, large investments and availability of expertise and labour is required for such a development.

For the studied region of Östergötland it is advantageous that several well-established actors already exist, producing ethanol and biogas, and that there are actors with know-how in biodiesel production. However, there is no biodiesel production plant for vehicle fuel. The ethanol production has mainly been based on grain and biogas production mainly on industrial food waste. The ethanol production has developed through increased valorisation of byproducts while the biogas industry has focused more on the supply side, leading to a more differentiated feedstock of wastes. If a gradual development towards a bio-based economy and an implementation of the biorefinery concept is going to take place, integration between new and existing technical and organizational infrastructure, new business partnerships to open markets, diffusion of knowledge as well as a change in the regulatory framework will be necessary [77]. To better address issues related to the implementation gap, it is important to strengthen research efforts aimed at understanding conditions for business development in the 
biofuel industry. To be able to influence the incubation time for implementation of sustainable biofuel production systems there is also a need for improved knowledge about existing and potential biofuel actors' apprehension of possibilities, drivers and barriers.

\section{Future perspective}

Potential investors in biofuels require knowledge about the long-term policy conditions for the industry, which are not in place. Other external factors such as competition for feedstock, prices of fossil fuels and other competing products, investments in infrastructure, etc. may also hamper the development. One example is that increased demand for bioenergy products in Sweden has increased the price volatility for straw and wood chips. So, there are uncertainties influencing investments in biofuel production. The future of other feedstock categories such as algae or reed depends more on technological development. The current article suggests that there is a large biofuel potential and that biogas technologies can play a key role in strengthening the sustainability performance of biofuels. What will happen however depends on the development of the complex networks of consistent policies, actions by companies and consumers, and technological development.

\section{Acknowledgements}

The authors would like to thank Tekniska Verken AB for contributing funding for this project through the IERP (Industrial Ecology Research Program), but also with expertise which made this study more credible. We also would like to thank the BRC (Biogas Research Centre) for the opportunity to further explore the findings in this study. We would also like to thank the reviewers for their comments that helped to improve this article.

\section{Executive summary}

\section{Background}

- Biofuels are expected to contribute significantly to the renewable share in the transportation sector.

- Östergötland is considered a leading-edge county in Sweden regarding biofuels in the transport sector, much due to a well-developed biogas production and distribution.

- $\quad$ The main aim of this study is to assess the feedstock potential for production of biofuels for road transport, in the county of Östergötland, Sweden in 2030.

- The study also aims at more generally contribute to knowledge on how to carry out similar assessments.

\section{Methodology}

- A resource-focused biofuel assessment was performed, where the data collection was based on an interview study and a literature review.

- $\quad$ The study included feedstock from the waste sector, agricultural sector, forestry sector and aquatic environments

- Two scenarios were constructed for the year 2030, EXPAN (Expansion scenario) and INNTEC (Innovation- and technology development scenario) partially considering technological and economic constraints 
Results

- $\quad$ The EXPAN scenario reached almost 30\% and the INNTEC scenario about 50\% of the assumed energy need for road transport in Östergötland in 2030 without including lignocellulose biomass from forestry.

- $\quad$ Assumptions regarding arable land for bioenergy (ley) production have major influence on the scenarios.

- A rough climate impact assessment based on generic figures in the European RES Directive indicates that the GHG emissions from road transport in Östergötland could be reduced by $23 \%$ and $39 \%$ in the EXPAN and INNTEC scenarios respectively.

\section{Concluding discussion}

- $\quad$ This paper gives insight into whether biofuels for road transport can play an important role in a Swedish county in the year 2030, and contributes to knowledge on how to perform similar studies.

- Without compromising with food security the study suggests that it is possible to significantly increase the biofuel production, and to do this as an integrated part of the existing society also contributing with positive societal synergies.

- $\quad$ There is a need to strengthen research efforts aimed at better addressing the implementation gap through understanding conditions for business development in the biofuel industry.

Defined key terms:

- Perennial crop

Crops that do not need yearly replanting, but where the above ground regrowth of biomass can be harvested on a yearly basis.

- Tall oil

A liquid by-product from the wood pulp industry which can be used to produce chemicals or fuel (e.g. biodiesel).

- Ley crop

The cropping of grasses and herbs where most part of the plant (the above ground part) is harvested for fodder or energy purposes.

- Fallow land Arable land that is not used for cropping but kept farmable.

- Ecosystem services

The benefits obtained from resources and processes supplied by natural ecosystems. 


\section{References}

1. European Commission. Energy roadmap 2050. (2011)

2. European Academies Science Advisory Council. The current status of biofuels in the European Union, their environmental impacts and future prospects. (EASAC, 2012)

3. European Union. Directive 2009/28/EC of the European Parliament and of the Council of 23 April 2009 on the promotion of the use of energy from renewable sources and amending and subsequently repealing Directives 2001/77/EC and 2003/30/EC. (2009).

4. European Union. 2003/30/EC Directive of the European Parliament and the Council, On the promotion of the use of biofuels or other renewable fuels for transport. (European Union, 2003)

5. European Commission. Innovating for Sustainable Growth: A Bioeconomy for Europe. European Commission. (European Union, Brussels, 2012)

6. OECD/FAO. OECD-FAO Agricultural Outlook 2012-2021,. (2012)

7. Igliński B, Buczkowski R, Iglińska A, Cichosz M, Piechota G, Kujawski W. Agricultural biogas plants in Poland: Investment process, economical and environmental aspects, biogas potential. Renewable and Sustainable Energy Reviews, 16(7), 4890-4900 (2012).

8. BP. BP Energy Outlook 2030. (British Petroleum Company, London, 2012)

9. Exxon Mobile. The outlook for energy - a view to 2040. (2013)

10. Swedish Energy Agency. Transportsektorns energianvändning 2011. (2012)

11. Ministry of Industry Employment and Communications. Fossiloberoende fordonsflotta - ett steg på vägen mot nettonollutsläpp av växthusgaser. Ministry of Industry Employment and Communications (Statens Offentliga Utredningar 2012)

12. Offermann R, Seidenberger T, Thrän D, Kaltschmitt M, Zinoviev S, Miertus S. Assessment of global bioenergy potentials. Mitigation and Adaptation Strategies for Global Change, 16(1), 103-115 (2011).

** Review of approaches in bioenergy assessment studies.

13. Berglund M, Börjesson P. Assessment of energy performance in the life-cycle of biogas production. Biomass and Bioenergy, 30(3), 254-266 (2006).

* Study showing possible benefits of production systems for biogas.

14. Palm R. The economic potential for production of upgraded biogas used as vehicle fuel in Sweden. (Chalmers University of Technology, Göteborg, 2010)

15. EU RES. Directive 2009/28/EC of the European Parliament and of the Council of 23 April 2009 on the promotion of the use of energy from renewable sources and amending and subsequently repealing Directives 2001/77/EC and 2003/30/EC. (2009) 
16. Kautto N, Peck P. Regional biomass planning - Helping to realise national renewable energy goals? Renewable Energy, 46(0), 23-30 (2012).

* Study emphasizing the importance of regional biomass assessment studies.

17. Bagliani M, Dansero E, Puttilli M. Territory and energy sustainability: The challenge of renewable energy sources. Journal of Environmental Planning and Management, 53(4), 457-472 (2010).

18. Berndes G, Hoogwijk M, Van Den Broek R. The contribution of biomass in the future global energy supply: A review of 17 studies. Biomass and Bioenergy, 25(1), 1-28 (2003).

19. Smeets E, Faaij A, Lewandowski I, Turkenburg W. A bottom-up assessment and review of global bio-energy potentials to 2050. Progress in Energy and Combustion Science, 33(1), 56-106 (2007).

20. Hoogwijk M. On the global and regional potential of renewable energy. In: University of Utrecht, Faculteit Scheikunde. (Univeristy of Utrecht, Utrecht, 2004)

21. Verbruggen A, Fischedick M, Moomaw W et al. Renewable energy costs, potentials, barriers: Conceptual issues. Energy Policy, 38(2), 850-861 (2010).

22. Lim S, Lee KT. Implementation of biofuels in Malaysian transportation sector towards sustainable development: A case study of international cooperation between Malaysia and Japan. Renewable and Sustainable Energy Reviews, 16(4), 1790-1800 (2012).

23. Legrand C, Weiss DS. How leaders can close the innovation gap. Ivey Business Journal, 75(4), 7-11 (2011).

24. Brings Jacobsen N. Do social factors really matter when companies engage in industrial symbiosis? Progress in Industrial Ecology, an International Journal, 4(6), 440-462 (2007).

25. Gunningham N, Sinclair, D.,. Acel final report: barriers and motivators to the adoption of cleaner production practices. (Australian Centre for Environmental Law; Jul. 1997. 115 p. Ilus, tab, Canberra, 1997)

26. Demirbas A. Political, economic and environmental impacts of biofuels: A review. Applied Energy, 86(SUPPL. 1), S108-S117 (2009).

27. Börjesson P. Good or bad bioethanol from a greenhouse gas perspective - What determines this? Applied Energy, 86(5), 589-594 (2009).

28. Martin M, Eklund, M. Improving the environmental performance of biofuels with industrial symbiosis. Biomass and Bioenergy, 35(5), 1747-1755 (2011).

** Study showing benefits of synergistic and integrated biofuel production systems.

29. Ammenberg J, Baas, L., Eklund, M., Feiz, R, Helgstrand, A., Marshall, R. Improving the $\mathrm{CO}_{2}$ performance of cement, part III: The relevance of industrial symbiosis and how to measure its impact. Manuscript submitted to the Journal of Cleaner Production, (2013). 
30. Feiz R, Ammenberg, J., Baas, L., Eklund, M., Helgstrand, A., Marshall, R. Improving the $\mathrm{CO} 2$ performance of cement, part II: Framework for assessing CO2 improvement measures in cement industry. . Manuscript submitted to the Journal of Cleaner Production, (2013).

31. Mangoyana RB, Smith TF. Decentralised bioenergy systems: A review of opportunities and threats. Energy Policy, 39(3), 1286-1295 (2011).

32. Mu D, Zhao, F., Seager, T., Rao, S.,. Integration of resilience perspective into sustainability assessment of biofuel production. In: International design Engineering Technical Conference \& Computers and Information in Engineering Conference. (ASME, Montreal, 2010)

33. Galik C, Hodgson W, Raborn C, Bean P. Integrating Biofuels into Comprehensive Climate Policy - An Overview of Biofuels Policy Options. Policy brief, (November 2009) (2009).

34. Hardy C, Graedel, T. E.,. Industrial Ecosystems as Food Webs. Journal of Industrial Ecology, 6(1) (2002).

35. Martin M. Industrial Symbiosis For The Development of Biofuel Production. In: Environmental Tachnology and Management. (Linköping University, Linköping, 2010)

36. Lantz M. Biogas in Sweden - Opportunities and challenges from a systems perspectiv. In: Environmental and Energy System Studies. (Lund University, Lund, 2013)

37. Solomon BD, Barnes JR, Halvorsen KE. Grain and cellulosic ethanol: History, economics, and energy policy. Biomass and Bioenergy, 31(6), 416-425 (2007).

38. Eklund M. Industrial symbiosis for the sustainable use of biofuels. Biofuels, 1(3), 373375 (2010).

39. Karlsson A. Befolkningsprognoser för Östergötlands län och kommuner samt Tranås kommun åren 2010-2030 (Östsam). (Statistics Sweden (SCB), 2010)

40. Lindroth A, Båth A. Assessment of regional willow coppice yield in Sweden on basis of water availability. Forest Ecology and Management, 121(1-2), 57-65 (1999).

41. Ragauskas AJ, Williams CK, Davison BH et al. The path forward for biofuels and biomaterials. Science, 311(5760), 484-489 (2006).

42. Westholm E, Beland Lindahl K. The Nordic welfare model providing energy transition? A political geography approach to the EU RES directive. Energy Policy, 50(0), 328-335 (2012).

43. Swedish Energy Agency. Transportsektorns energianvändning. In: ES 2011:05. (Energimyndigheten, 2011) 
44. Cherubini F. The biorefinery concept: Using biomass instead of oil for producing energy and chemicals. Energy Conversion and Management, 51(7), 1412-1421 (2010).

45. Ersson C, Eklund, M., Ammenberg, J., Ivner, J. Vision för biodrivmedel i Östergötland - Tillgång på regionala råvaror och principer för en resurseffektiv produktion år 2030. (Linköping university, 2012)

** This report gives a more extensive presentation of the study in this article.

46. Börjesson P, Mattiasson B. Biogas as a resource-efficient vehicle fuel. Trends in Biotechnology, 26(1), 7-13 (2008).

47. Singh J, Gu S. Commercialization potential of microalgae for biofuels production. Renewable and Sustainable Energy Reviews, 14(9), 2596-2610 (2010).

48. Karltorp K, Sandén BA. Explaining regime destabilisation in the pulp and paper industry. Environmental Innovation and Societal Transitions, 2(0), 66-81 (2012).

49. Näyhä A, Pesonen H-L. Diffusion of forest biorefineries in Scandinavia and North America. Technological Forecasting and Social Change, 79(6), 1111-1120 (2012).

50. Xie XM, Zhou F, Zhao YH, Lu XL. A summary of ecological and energy-producing effects of perennial energy grasses. Shengtai Xuebao/ Acta Ecologica Sinica, 28(5), 2329-2342 (2008).

51. Lantbrukarnas Riksförbund. Energistrategi - Nulägesbeskrivning för LRFs energistrategi, ett arbetsdokument för en samlad energistrategi (2011)

52. Larsson MP, Morell, M., Myrdal, J. Agrarhistoria. Natur och kultur/LTs förlag, (1997).

53. Gerbens-Leenes W, Nonhebel S. Food and land use. The influence of consumption patterns on the use of agricultural resources. Appetite, 45(1), 24-31 (2005).

54. Gerbens-Leenes PW, Nonhebel S. Consumption patterns and their effects on land required for food. Ecological Economics, 42(1-2), 185-199 (2002).

55. Swedish Energy Agency. Sustainable biofuels 2011. (Swedish Energy Agency, Eskilstuna, 2012)

56. Jokela B. Cropping system effects on soil quality. In: Wisconsin Crop Management Conference 2011. (Madison, Wisconsin, 2011)

57. Weiland P. Biogas production: current state and perspectives. Applied Microbiology and Biotechnology, 85(4), 849-860 (2010).

58. Singh A, Nizami A-S, Korres NE, Murphy JD. The effect of reactor design on the sustainability of grass biomethane. Renewable and Sustainable Energy Reviews, 15(3), 1567-1574 (2011).

59. Smyth BM, Ó Gallachóir BP, Korres NE, Murphy JD. Can we meet targets for biofuels and renewable energy in transport given the constraints imposed by policy in agriculture and energy? Journal of Cleaner Production, 18(16-17), 1671-1685 (2010). 
60. Hansson A, Tjernström, E., Gradin, M. \& Finnis, P.,. Wetlands Algae Biogas - A Southern Baltic Sea Eutrophication Counteract Project. (Trelleborg, 2012)

61. Mussgnug JH, Klassen V, Schlüter A, Kruse O. Microalgae as substrates for fermentative biogas production in a combined biorefinery concept. Journal of Biotechnology, 150(1), 51-56 (2010).

62. Gunnarsson M, Lygnegård, T. Östergötland biogasring - Möjlighet till lokal biogasproduktion i Östergötland län. (2008)

63. Benjaminsson J, Linné, M. Biogasanläggningar med 300 GWh årsproduktion system, teknik och ekonomi. (SGC, 2007)

64. Reijnders L, Huijbregts MAJ. Nitrous oxide emissions from liquid biofuel production in life cycle assessment. Current Opinion in Environmental Sustainability, 3(5), 432437 (2011).

65. Avfall Sverige. Den svenska biogaspotentialen från inhemska råvaror. In: Rapport 2008:02. (Avfall Sverige Utveckling, 2008)

66. Swedish Board of Agriculture. Miljöeffekter av träda och olika växtföljder - rapport från projektet CAP:s miljöeffekter. (2006)

67. Davis AS, Hill JD, Chase CA, Johanns AM, Liebman M. Increasing Cropping System Diversity Balances Productivity, Profitability and Environmental Health. PLoS ONE, 7(10), e47149 (2012).

68. Wrigley EA. The supply of Raw Materials in the Industrial Revolution. The Economic History Review, 15 (1), 1-16 (1962).

69. Martin M, Svensson N, Eklund M, Fonseca J. Production synergies in the current biofuel industry: opportunities for development. Biofuels, 3(5), 545-554 (2012).

70. De Wilt J. Ecopyramid: Proper utilization of biomass! In: Concept guide. (InnovatienNetwerk, 2008)

* $\quad$ A concept guide showing why biofuel production systems should be designed as biorefineries.

71. Ericsson K, Rosenqvist H, Nilsson LJ. Energy crop production costs in the EU. Biomass and Bioenergy, 33(11), 1577-1586 (2009).

72. Lantz M, Svensson M, Björnsson L, Börjesson P. The prospects for an expansion of biogas systems in Sweden-Incentives, barriers and potentials. Energy Policy, 35(3), 1830-1843 (2007).

73. Dolan T, Cook MB, Angus AJ. Financial appraisal of wet mesophilic AD technology as a renewable energy and waste management technology. Science of The Total Environment, 409(13), 2460-2466 (2011). 
74. Berglund M. Biogas Production from a Systems Analytical Perspective. In: Environmental and Energy Systems Studies. (Lund University, Lund, 2006)

75. Lybæk R, Christensen TB, Kjær T. Governing Innovation for Sustainable Development in the Danish Biogas Sector - a Historical Overview and Analysis of Innovation. Sustainable Development, n/a-n/a (2012).

* Study illustrating the importance of policy programs and governance for the devlopment of biofuel production systems.

76. Lantz M, Svensson M, Björnsson L, Börjesson P. The prospects for an expansion of biogas systems in Sweden-Incentives, barriers and potentials. Energy Policy, 35(3), 1830-1843 (2007).

77. Ekman A. Environmental Assessment of Emerging Bio-based Production Possibilites in a future Bio-economy. In: Lund university, Environment and Energy Systems Studies. (Lund University, Lund, 2012)

* $\quad$ Thesis stressing the need to strengthen research efforts on implementation issues and business development in the biomass based industry.

101. European Renewable Energy Council. Statistics, RES-E share, RES-T share. http://www.erec.org/statistics.html. (Accessed 20 December 2012)

102. Swedish Bioenergy Association (Svebio). Fakta om bioenergi. http://www.svebio.se/fakta-om-bioenergi. (Accessed 12 November 2012)

103. Swedish Board of Agriculture SJV. Jordbruksmarkens användning http://statistik.sjv.se/Database/Jordbruksverket/Markanvandning/Markanvandning.asp. (Accessed 10 January 2012) 